\title{
SUITABILITYOF DIFFERENT WINTER VEGETABLES WITH SWEET GOURD
}

\author{
S.S. Kakon ${ }^{1 *}$, J.A. Chowdhury ${ }^{1}$, M.M. Bazzaz ${ }^{2}$, M.M. Alam ${ }^{3}$, A.A. Begum ${ }^{1}$, M. A. Aziz ${ }^{1}$ \\ ${ }^{1}$ Agronomy Division, Bangladesh Agricultural Research Institute, Joydebpur Gazipur 1701, Bangladesh \\ 2 Agricultural Research Station, Rajbari, Dinajpur \\ ${ }^{3}$ Regional Agricultural Research Station, Hathazari, Chittagong \\ "Corresponding Author, E-mail: kakonbari@gmail.com
}

(Received: 14 September 2017, Accepted: 11 April 2019)

\begin{abstract}
The experiment was conducted at Joydebpur and Rajbari Farm of Bangladesh Agricultural Research Institute during two successive rabi seasons (2014-16) to find out the suitable vegetable for intercropping with sweet gourd for higher productivity and economic return. Six intercrop combinations of sweet gourd and vegetables viz., $\mathrm{T}_{1}=$ Sole sweet gourd, $\mathrm{T}_{2}=$ Sweet gourd $(2 \mathrm{~m} \times 2 \mathrm{~m})+$ cabbage $(50 \mathrm{~cm} \times 50$ $\mathrm{cm}), \mathrm{T}_{3}=$ Sweet gourd $(2 \mathrm{~m} \times 2 \mathrm{~m})+$ cauliflower $(50 \mathrm{~cm} \times 50 \mathrm{~cm}), \mathrm{T}_{4}=$ Sweet gourd $(2 \mathrm{~m} \times 2 \mathrm{~m})+$ radish $(20 \mathrm{~cm} \times 25 \mathrm{~cm}), \mathrm{T}_{5}=$ Sweet gourd $(2 \mathrm{~m} \times 2 \mathrm{~m})+$ lettuce $(50 \mathrm{~cm} \times 50 \mathrm{~cm}), \mathrm{T}_{6}=$ Sweet gourd $(2$ $\mathrm{m} \times 2 \mathrm{~m})$ + tomato $(50 \mathrm{~cm} \times 50 \mathrm{~cm})$ were tested at Joydebpur and Rajbari. The highest mean sweet gourd yield (31.37 t ha ${ }^{-1}$ at Joydebpur and $34.54 \mathrm{t} \mathrm{ha}^{-1}$ at Rajbari) was recorded in sole sweet gourd over the years. The highest mean vegetable yield $\left(42.87 \mathrm{t} \quad \mathrm{ha}^{-1}\right.$ at Joydebpur and $61.40 \mathrm{t} \mathrm{ha}^{-1}$ at Rajbari) was recorded in sweet gourd + cabbage combination. Maximum mean sweet gourd equivalent (SEY) yield $(72.55 \mathrm{t}$ $\mathrm{ha}^{-1}$ ), highest gross return (Tk. $362775 \mathrm{ha}^{-1}$ and BCR (2.98) were recorded in sweet gourd + cabbage combination over the years at Joydebpur. The maximum mean SEY $\left(79.38 \mathrm{t} \mathrm{ha}^{-1}\right)$, highest gross return (Tk. $396905 \mathrm{ha}^{-1}$ ) and BCR (3.25) were recorded in sweet gourd + cauliflower combination at Rajbari. Two year results revealed that sweet gourd + cabbage and cauliflower might be suitable intercrop combination for getting maximum yield and economic return.
\end{abstract}

\section{Introduction}

Bangladesh is a small country but food demand is high due to high rate of population growth. In order to produce more food within a limited area, one of the most important options is to increase the cropping intensity producing two or more crops over the same piece of land. Vegetables are the main component of human food that supplies proteins, carbohydrates, fats, vitamins and minerals. Our vegetable production is much less than the requirement. However, limited scope of bringing additional land for vegetable production, demands intervention of growing more vegetables per unit area and time i.e., intercropping. While intercropping is widely practiced with cereals, the benefits of intercropping vegetables both from our economic and dietary aspects have been largely ignored. Intercropping of legume vegetables with other vegetables may increase vegetable consumption and develop soil fertility through symbiotic nitrogen fixation (Willey, 1979)

Intercropping is one of the cropping strategies that have been recognized to improve the food security situation and incomes for the farmers (Mahfuza, 2012). 
Intercropping also helps to reduce weed populations, insect pest infestation and risk of complete crop failure (Amede, 2001; Islam et al., 2013).

Intercropping system becomes more productive and profitable when it is done properly by selecting compatible crops (Begum et al., 2010) and increasing vegetable productivity (Rashid, 1987). Sweet gourd is an important vegetable sown with wide spacing, and may be grown in both rabi and kharif season. Different winter vegetables (cabbage, cauliflower, radish, lettuce and tomato) may be grown in association with sweet gourd. However, some farmers of Panchagar and Khulna districts have been practicing sweet gourd intercropping with tomato and cauliflower instead of sole cropping. Different farmers use different winter vegetables for intercropping with sweet gourd. This experiment was conducted to select suitable vegetables for intercropping with sweet gourd.

\section{Materials and Methods}

The experiment was conducted at the research field of Agronomy Division, BARI, Joydebpur, Gazipur and ARS, Rajbari during rabi seasons of 2014-15 and 201516. Six intercrop combinations of sweet gourd and winter vegetables viz., $\mathrm{T}_{1=}$ Sole sweet gourd, $\mathrm{T}_{2}=$ Sweet gourd $(2 \mathrm{~m} \times 2 \mathrm{~m})+$ cabbage $(50 \mathrm{~cm} \times 50 \mathrm{~cm})$, $\mathrm{T}_{3}=$ Sweet gourd $(2 \mathrm{~m} \times 2 \mathrm{~m})+$ cauliflower $(50 \mathrm{~cm} \times 50 \mathrm{~cm}), \mathrm{T}_{4}=$ Sweet gourd $(2 \mathrm{~m} \times 2 \mathrm{~m})+\operatorname{radish}(20 \mathrm{~cm} \times 25 \mathrm{~cm}), \mathrm{T}_{5}=$ Sweet gourd $(2 \mathrm{~m} \times 2 \mathrm{~m})+$ lettuce $(50 \mathrm{~cm} \times 50 \mathrm{~cm}), \mathrm{T}_{6}=$ Sweet gourd $(2 \mathrm{~m} \times 2 \mathrm{~m})+$ tomato $(50 \mathrm{~cm} \times 50 \mathrm{~cm})$ were tested The experiment was laid out in a RCB design with 3 replications. The unit plot size was $4 \mathrm{~m}$ x $4 \mathrm{~m}$. Sweet gourd var. BARI Misti kumra-2, Cabbage var. BARI Badhacopy-1, Cauliflower var. BARI Fulcopy-1, Tomato var. BARI Tomato-2, Lettuce var. BARI lettuce-1 and radish var. BARI Mula-1 were used. Seeds of radish were sown on 25 November at Joydebpur and twenty five days old seedlings of cabbage, cauliflower, lettuce and tomato were transplanted on the same day in both the years. On the other hand, at Rajbari, seeds of radish were sown on 25 November 2014 and 09 November 2015 and twenty five days old seedlings of cabbage, cauliflower, lettuce and tomato were transplanted on the same day in both the years. Thirty days old seedlings of sweet gourd were transplanted on 12 December 2014 and 19 November 2015. Thirty days old seedlings of sweet gourd were transplanted on 10 December in both the years at Joydebpur and different winter vegetables were planted in line according to the treatments at 15 days before transplanting of sweet gourd seedlings. Fertilizers @ 80-36-100-24-2-2 kg ha ${ }^{-1}$ NPKSZnB + CD: $10 \mathrm{t} \mathrm{ha}^{-1}$ were applied in sole sweet gourd Chemical fertilizers were used in the form of urea, triple super phosphate, muriate of potash, gypsum, zinc sulphate and boric acid. Fertilizers @ 100-50.5-90.5-18-2.3 kg ha-1 NPKSZnB + CD: $10 \mathrm{t} \mathrm{ha}{ }^{-1}$ were applied in vegetables. Organic manure and chemical fertilizers were applied at the final land preparation, while urea and MoP were top dressed in two equal splits at 15 and 35 DAT of winter vegetables. All chemical fertilizer along with organic manure was applied in pit 7 days before transplanting of winter vegetables and sweet gourd seedlings.

At Joydebpur sweet gourd harvesting was started from 93 DAT and four harvesting was done up to 1 -5 April 2015 and 2016. Cabbage and Cauliflower was harvested two times (55 and 70 DAT). Lettuce was harvested at 35 DAT and tomato was harvested four times at 85, 90, 93 and 100 DAT in both the years. On the other hand, at Rajbari, sweet gourd harvesting was started from 105 DAT and harvesting was done four times. Cauliflower was harvested three times (59, 68 and 74 DAT). Lettuce was harvested at 45 and 55 DAT and tomato was harvested five times at 91, 98, 105, 112, 119, and 126 DAT in both the years. Intercultural operations like watering, weeding and pest control 
were done as and when required. Yields of both the crops were taken from whole plot. Collected data of all crops were analyzed statistically and the means were adjudged using LSD test at 5\% level. Benefit- cost analysis was also done. Sweet gourd equivalent yield was computed using the formula of Bandyopadhaya (1984).

Sweet gourd equivalent yield (SEY) $\left(\mathrm{kg} \mathrm{ha}^{-1}\right)=$ Yisg $+\frac{\text { Yiveg.Pveg. }}{\mathrm{Psg}}$

Where, Yi sg $=$ Sweet gourd yield $\left(\mathrm{kg} \mathrm{ha}^{-1}\right)$ in intercropping.

Yiv eg. = Veg. yield $\left(\mathrm{kg} \mathrm{ha}^{-1}\right)$ in intercropping

Psg = Price of sweet gourd $\left(\mathrm{kg} \mathrm{ha}^{-1}\right)$

Pveg. = Price of vegetable $\left(\mathrm{kg} \mathrm{ha}^{-1}\right)$

\section{Results and Discussion}

\section{Yield and yield component of Sweet gourd}

Number of fruits plant ${ }^{-1}$ and fruit yield of sweet gourd were significantly affected by the treatments (Table 1) in both the years. The maximum number of fruits/plant (8.83 in 2014-15 and 6.57 in 2015-16 at Joydebpur and 6.3 in 2014-15 and 3.33 in 2015-16 at Rajbari) were obtained from sole sweet gourd treatment but at par to other treatment except $\mathrm{T}_{6}$ which produced lowest fruits plant $^{-1}$. Similar trend was followed in case of single fruit weight. The maximum fruit yield (35.89 and $26.84 \mathrm{t} \mathrm{ha}^{-1}$ at Joydebpur and 33.87 and $35.21 \mathrm{t} \mathrm{ha}^{-1}$ at Rajbari) were obtained from sole sweet gourd and the lowest (16.33 and 19.71 $\mathrm{t} \mathrm{ha}^{-1}$ at Joydebpur and 7.64 and $8.01 \mathrm{t} \mathrm{ha}^{-1}$ at Rajbari) in sweet gourd + tomato in 2014-15 and 2015-16, respectively. At Joydebpur, sweet gourd yield was lower in 2015-16 than $1^{\text {st }}$ year due to heavy rainfall at flowering stage which produced lower photosynthetic rate caused lower yield. The higher yield in sole crop might be due to the utilization of wider space and less competition for natural resources. Ali et al. (2003) also reported similar result. Among the intercropped treatments, $\mathrm{T}_{5}$ treatment (sweet gourd + lettuce) produced higher fruit yield $\left(35.54,25.73 \mathrm{t} \mathrm{ha}^{-1}\right.$ at Joydebpur) might be due to early harvesting of lettuce and less competition of different growth resources. On the other hand, at Rajbari $\mathrm{T}_{4}$ treatment produced slightly higher fruit yield (29.63 and $31.82 \mathrm{t} \mathrm{ha}^{-1}$ ) of sweet gourd in both the years. In pooled analysis, friut yield showed maximum in sole situation (Table 2)

Table 1. Fruit yield and yield components of sweet gourd in sole intercropping system in Rabi seasons of 2014-15 and 2015-16 at Joydebpur and Rajbari

\begin{tabular}{|c|c|c|c|c|c|c|c|c|c|c|c|c|}
\hline \multirow[t]{4}{*}{ Vegetables } & \multicolumn{4}{|c|}{ Fruits plant $^{-1}$ (no.) } & \multicolumn{4}{|c|}{ Single fruit wt. (kg) } & \multicolumn{4}{|c|}{ Fruit yield $\left(\mathrm{t} \mathrm{ha}^{-1}\right)$} \\
\hline & \multicolumn{2}{|c|}{ Joydebpur } & \multicolumn{2}{|c|}{ Rajbari } & \multicolumn{2}{|c|}{ Joydebpur } & \multicolumn{2}{|c|}{ Rajbari } & \multicolumn{2}{|c|}{ Joydebpur } & \multicolumn{2}{|c|}{ Rajbari } \\
\hline & 2014- & 2015- & 2014- & 2015- & 2014- & 2015- & 2014- & 2015- & 2014- & 2015- & 2014- & $2015-$ \\
\hline & 15 & 16 & 15 & 16 & 15 & 16 & 15 & 16 & 15 & 16 & 15 & 16 \\
\hline $\mathrm{T}_{1}$ & 8.83 & 6.57 & 6.3 & 3.33 & 1.95 & 1.84 & 2.02 & 4.30 & 35.89 & 26.84 & 33.87 & $\overline{35.21}$ \\
\hline $\mathrm{T}_{2}$ & 8.33 & 6.37 & 5.7 & & 1.94 & 1.75 & 1.89 & 3 & 34.62 & 24.76 & 17.02 & 77 \\
\hline $\mathrm{T}_{3}$ & 8.20 & 6.24 & 5.9 & 2. & 1.81 & 1.75 & 1.97 & 4.20 & 33.04 & 21.84 & 20.96 & 01 \\
\hline $\mathrm{T}_{4}$ & 8.53 & 6.51 & 5.7 & 3. & 1.91 & 1.79 & 1.99 & 4. & 34.35 & 24.50 & 29.63 & 31.82 \\
\hline $\mathrm{T}_{5}$ & 8.63 & 6.40 & 5.5 & 2.9 & 1.87 & 1.81 & 1.87 & 3. & 35.54 & 25.73 & 29.47 & 24.37 \\
\hline $\mathrm{T}_{6}$ & 5.57 & 3.83 & 3.6 & 1.75 & 1.35 & 1.57 & 1.51 & 3.12 & 16.33 & 19.71 & 7.64 & 8.01 \\
\hline $\mathrm{LSD}_{\|}$ & 1.56 & 1.10 & 1.33 & 0.71 & 0.19 & 0.141 & 0.17 & 0.64 & 3.41 & 3.23 & 3.67 & 3.37 \\
\hline CV $(\%)$ & 8.9 & 10.06 & 4.44 & 8.02 & 5.79 & 4.26 & 6.07 & 9.05 & 5.93 & 7.42 & 8.80 & 8.10 \\
\hline
\end{tabular}


$\mathrm{T}_{1}=$ Sweet gourd $(2 \mathrm{~m} \times 2 \mathrm{~m}), \mathrm{T}_{2}=$ Sweet gourd $(2 \mathrm{~m} \times 2 \mathrm{~m})+$ cabbage $(50 \mathrm{~cm} \times 50$ $\mathrm{cm}), \mathrm{T}_{3}=$ Sweet gourd $(2 \mathrm{~m} \times 2 \mathrm{~m})+$ cauliflower $(50 \mathrm{~cm} \times 50 \mathrm{~cm}), \mathrm{T}_{4}=$ Sweet gourd $(2 \mathrm{~m}$ $\times 2 \mathrm{~m})+\operatorname{radish}(20 \mathrm{~cm} \times 10 \mathrm{~cm}), \mathrm{T}_{5}=$ Sweet gourd $(2 \mathrm{~m} \times 2 \mathrm{~m})+$ lettuce $(50 \mathrm{~cm} \times 50$ $\mathrm{cm}), \mathrm{T}_{6}=$ Sweet gourd $(2 \mathrm{~m} \times 2 \mathrm{~m})+$ tomato $(50 \mathrm{~cm} \times 50 \mathrm{~cm})$

\section{Winter vegetables}

The highest cabbage yield (38.32 and $47.42 \mathrm{t} \mathrm{ha}^{-1}$ at Joydebpur and 58.31 and $64.49 \mathrm{t} \mathrm{ha}^{-1}$ at Rajbari) was recorded in sweet gourd + cabbage combination and the lowest yield (10.59 and $10.84 \mathrm{t} \mathrm{ha}^{-1}$ at Joydebpur) in $\mathrm{T}_{5}$ treatment in both the years. Whereas, at Rajbari, the lowest lettuce yield 12.49 and $13.21 \mathrm{t}$ ha $^{-1}$ were recorded from sweet gourd + lettuce and sweet gourd + radish combination in 2014-15 and 2015-16, respectively.

\section{Intercrop efficiency}

Sweet gourd equivalent yield and benefit cost analysis of sole and intercropping are presented in Table 3. Sweet gourd equivalent yields (SEY) in all intercropping systems were higher than sole sweet gourd $\left(35.89 \mathrm{t} \mathrm{ha}^{-1}\right)$ indicating higher productivity of intercropping systems. Similar results were mentioned by Alom et al. (2013). Among the intercropping systems, maximum SEY was $72.55 \mathrm{t} \mathrm{ha}^{-1}$ was recorded in sweet gourd + cabbage combination which was followed by sweet gourd + cauliflower combination (69.99 $\mathrm{t} \mathrm{ha} \mathrm{h}^{-1}$ ) at Joydebpur. Higher SEY in these combinations might be contributed by combined effect of both the components. Maximum gross return (Tk. $362775 \mathrm{ha}^{-1}$ ) was recorded in sweet gourd + cabbage combination which was close to sweet gourd + cauliflower combination. This treatment showed the highest BCR (2.98) which was also close to sweet gourd + radish combination (2.90) at Joydebpur. This result is in agreement with the finding of Islam et al. (2013). At Rajbari, the highest SEY (79.38 $\mathrm{t} \mathrm{ha}^{-1}$ ) and gross return (Tk. $396905 \mathrm{ha}^{-1}$ ) was recorded in sweet gourd + cauliflower combination which was close to sweet gourd + cabbage combination. This treatment showed the highest mean BCR (3.25).

Table 2. Yield of different winter vegetables with sweet gourd (mean), sweet gourd equivalent yield (SEY) and cost and return analysis (average of two years) at Joydebpur and Rajbari

\begin{tabular}{|c|c|c|c|c|c|c|c|c|c|c|c|c|}
\hline \multirow[t]{2}{*}{ Treatment } & \multicolumn{2}{|c|}{$\begin{array}{l}\text { Fruit yield } \\
\left(\mathrm{t} \mathrm{ha}^{-1}\right)\end{array}$} & \multicolumn{2}{|c|}{$\begin{array}{c}\text { Vegetable } \\
\left(\mathrm{t} \mathrm{ha}^{-1}\right)\end{array}$} & \multicolumn{2}{|c|}{$\begin{array}{l}\text { SEY } \\
\left(\mathrm{t} \quad \mathrm{ha}^{-1}\right)\end{array}$} & \multicolumn{2}{|c|}{$\begin{array}{l}\text { Cost of } \\
\text { cultivation } \\
\left(\text { Tk ha }{ }^{-1}\right)\end{array}$} & \multicolumn{2}{|c|}{$\begin{array}{c}\text { Gross } \\
\text { return } \\
\left(\mathrm{Tk} \quad \mathrm{ha}^{-1}\right)\end{array}$} & \multicolumn{2}{|c|}{$\mathrm{BCR}$} \\
\hline & Joy. & Raj. & Joy. & Raj. & Joy. & Raj. & Joy. & Raj. & Joy. & Raj. & Joy. & Raj. \\
\hline $\mathrm{T}_{1}$ & 31. & 34. & & & 31. & 34. & 112 & 110 & 156 & 172 & 1.41 & 1.57 \\
\hline & 37 & 54 & & & 37 & 54 & 500 & 000 & 825 & 700 & & \\
\hline $\mathrm{T}_{2}$ & 29. & 16. & 42. & 61. & 72. & 77 & 121 & 120 & 362 & 388 & 2.98 & 3.22 \\
\hline & 69 & 40 & 87 & 40 & 55 & 8 & 700 & 70 & 775 & 975 & & \\
\hline $\mathrm{T}_{3}$ & 27. & 21. & 21. & 36 & 69. & 79 & 122 & 122 & 349 & 396 & 2.84 & 3.25 \\
\hline & 44 & 49 & 28 & 1 & 99 & 3 & 000 & 000 & 950 & & & \\
\hline $\mathrm{T}_{4}$ & 29. & 30. & 38. & 19. & 68. & 62. & 123 & 117 & 340 & 312 & 2.90 & 2.66 \\
\hline & 43 & 7 & 76 & 82 & 18 & 4 & 315 & 500 & 900 & 1 & & \\
\hline $\mathrm{T}_{5}$ & 30. & 26. & 10. & 14 & 56 & 45 & 11 & 115 & 281 & 247 & 2.44 & 2.15 \\
\hline & 64 & 42 & 72 & 38 & 36 & 4 & 825 & 000 & 775 & 140 & & \\
\hline $\mathrm{T}_{6}$ & 18. & 7.8 & 35 & 40 & 66 & 48 & 126 & 125 & 333 & 242 & 2.65 & 1.94 \\
\hline & 02 & 3 & 05 & 62 & 65 & 44 & 105 & 000 & 250 & 200 & & \\
\hline
\end{tabular}

$\mathrm{T}_{1}=$ Sole sweet gourd $\mathrm{T}_{2}=$ Sweet gourd $(2 \mathrm{~m} \times 2 \mathrm{~m})+$ cabbage $(50 \mathrm{~cm} \times 50 \mathrm{~cm}), \mathrm{T}_{3}=$ Sweet gourd $(2 \mathrm{~m} \mathrm{x} 2 \mathrm{~m})+$ cauliflower $(50 \mathrm{~cm} \times 50 \mathrm{~cm}), \mathrm{T}_{4}=$ Sweet gourd $(2 \mathrm{~m} \times 2$ $\mathrm{m})+$ radish $(20 \mathrm{~cm} \times 10 \mathrm{~cm}), \mathrm{T}_{5}=$ Sweet gourd $(2 \mathrm{~m} \times 2 \mathrm{~m})+$ lettuce $(50 \mathrm{~cm} \times 50 \mathrm{~cm})$, $\mathrm{T}_{6}=$ Sweet gourd $(2 \mathrm{~m} \times 2 \mathrm{~m})+$ tomato $(50 \mathrm{~cm} \times 50 \mathrm{~cm}), \mathrm{SEY}=$ Sweet gourd equivalent yield

Market price $\left(\mathrm{Tk} \mathrm{kg}^{-1}\right)$ : Sweet gourd- 5/-, Cabbage- 5/-, Cauliflower- 10/-, Radish- 10/-, Lettuce- 12/- and Tomato- 5/- at Joydebpur, Sweet gourd-5/-, Cabbage- 5/-, Cauliflower- 8/-, Radish- 8/-, Lettuce -8/- and Tomato- 5/- at Rajbari 


\section{Conclusion}

The overall results indicated that among the intercrop combinations sweet gourd $(2 \mathrm{~m} \times 2 \mathrm{~m})$ + cabbage / cauliflower $(50 \mathrm{~cm} \times 50 \mathrm{~cm})$ combination was found suitable for total productivity and economic return at Rajbari but at Joydebpur sweet gourd (2 m x $2 \mathrm{~m})$ + cabbage / raddish was found viable..

\section{References}

Ali, M. Y., M. S. Islam, A. K. M. M. Rahman, M. M. Hossain and M. M. Haque. 2003. Economic performance of tomato intercropping with vegetables. Bangladesh J. Agril. Res. 28(4): 619-623.

Alom, M. S., B. L. Nag, M. N. Islam, F. Ahmed and S. Akther 2013. Performance of different crop species with pointed gourd (Trichosanthes dioica Roxb.) Bangladesh J. Agril. Res. 38(3): 523-529.

Amede, T. and Y. Nigatu. 2001. Interaction of Components of Sweetpotato-maize Intercropping under the Semi-arid conditions of the Rift-Valley, Ethiopia. Tropical Agriculture. 78(1): 1-7.

Begum, S., M. N. Islam, M. T. Rahman, J. A. Chowdhury. and M. I. Haque. 2010. Suitability study of different chili varieties for intercropping with sweet gourd. J. Exp. Biosci. 1(2): 1-4.

Bandyopadhyay, S. N. 1984. Nitrogen and water relations in grain sorghum-legume intercropping systems. Ph. D. Dissertation, Indian Agricultural Research Institute, New Delhi.

Islam, M. N., M. S. Rahman, F. Ahmed, M. S. Alom and M. Akhteruzzaman. 2013. Performance of different HYV mustard varieties with sugarcane (Sacchaarum officinarum) as intercrop in farmers' fields. Bangladesh J. Agril. Res. 38(1): 137-143.

Mahfuza, S. N., M. N. Islam, A. Hannan, M. Akhteruzzaman and S. Begum. 2012. Intercropping of different vegetables and spices with pointed gourd. J. Exp. Biosci. 3(1):77-82.

Rashid, M. A. 1987. Effect of intercropping cabbage and Batisak at varying plant population levels. M.Sc. (Ag.) Thesis, Department of Horticulture, BAU, Mymensingh. 